\title{
Spatial and Temporal Variation of Carotenoids in Four Species of Trentepohlia (Trentepohliales, Chlorophyta)
}

\author{
Diana Kharkongor and Papiya Ramanujam \\ Algal Ecology Laboratory, Centre for Advanced Studies in Botany, Department of Botany, School of Life Sciences, \\ North-Eastern Hill University, Shillong, Meghalaya 793022, India
}

Correspondence should be addressed to Diana Kharkongor; dianakharkongor@gmail.com

Received 30 September 2015; Revised 30 November 2015; Accepted 30 November 2015

Academic Editor: Bernd Schneider

Copyright (C) 2015 D. Kharkongor and P. Ramanujam. This is an open access article distributed under the Creative Commons Attribution License, which permits unrestricted use, distribution, and reproduction in any medium, provided the original work is properly cited.

\begin{abstract}
Trentepohlia Martius, a dominant green subaerial alga, grows abundantly in Shillong and imparts the yellow, red, and orange colours to most of the tree barks, walls, rocks, and electric poles because of high accumulation of carotenoids in their filaments. This study emphasised the seasonal changes in carotenoid content amongst four different species of Trentepohlia, that is, T. diffracta, T. arborum, T. umbrina, and T. abietina, collected from four different substrata, that is, wall, rock, electric pole, and three types of tree bark (smooth, fissured, and rough). Quantitative estimation of different carotenoids, namely, $\beta$-cryptoxanthin, lutein, and $\beta$-carotene, from HPLC chromatogram peak showed a significant seasonal variation in all of the four species and $\beta$-carotene was threefold more in winter compared to summer. Amongst the selected species, T. diffracta collected from wall contained the highest amount of $\beta$-carotene both in summer and in winter, followed by T. arborum from rock and T. abietina from bark, and least amount was in T. umbrina collected from electric pole. Comparing the carotenoid content in Trentepohlia abietina growing in different types of barks, sample from smooth bark had the highest amount of carotenoids both in summer and in winter, followed by the sample from rough bark, and lowest amount was noted in fissured bark.
\end{abstract}

\section{Introduction}

Carotenoids are naturally occurring pigments synthesized by plants, algae, and photosynthetic bacteria. Carotenoids are classified into two classes, carotenes or carotenoid hydrocarbons, for example, lycopene, $\alpha$-carotene, and $\beta$-carotene, and xanthophylls or oxygenated carotenoids, for example, $\beta$ cryptoxanthin, lutein, and zeaxanthin [1]. Carotenoids have received tremendous attention because of their various functions in plants, animals, and humans. In plants, carotenoids have the important antioxidant function of quenching singlet oxygen formed during photosynthesis [2]. These compounds are precursors of vitamin $\mathrm{A}$ and retinoid compounds required for morphogenesis in animals and humans [3,4]. Carotenoids are widely utilised in pharmaceutical purposes as health supplements and in food industries as natural colorants [5]. $\beta$-Carotene and $\beta$-cryptoxanthin are two carotenoids that show essential functions in humans where they serve as source of vitamin A $[6,7]$. Besides being precursor of vitamin
$\mathrm{A}, \beta$-carotene and $\beta$-cryptoxanthin are excellent antioxidants $[8-10]$. $\beta$-Cryptoxanthin and lutein have got anticancer properties [11-13]. Moreover lutein is a good antioxidant as well $[14,15]$ and it is one of the macular pigments that play an important role in maintaining eye health and in reduction of macular degeneration $[16,17]$.

Trentepohlia Martius, belonging to the order Trentepohliales and class Ulvophyceae, is a dominant subaerial green alga of Shillong region and grows abundantly on different substrata, whereby its presence imparts yellow, orange, and red colours to the substrata due to accumulation of carotenoids in the filaments. Frequent occurrence of Trentepohlia on rocks, buildings, and tree barks had been reported by many workers [18-23]. Presence of specific carotenoids in Trentepohlia iolithus had been well documented by Kjosen et al. [24] and by Nybraaten and Liaaen-Jensen [25] whereas eight types of carotenoids had been reported in Trentepohlia gobii [26]. Abe et al. $[27,28]$ had demonstrated the accumulation of carotenoids in T. aurea and the simultaneous production of 
TABLE 1: Total rainfall ( $\mathrm{mm}$ ), average minimum and average maximum temperature during sampling months, that is, summer (June, July, and August) and winter (December, January, and February).

\begin{tabular}{|c|c|c|c|c|c|c|c|}
\hline \multicolumn{4}{|c|}{ Summer } & \multicolumn{4}{|c|}{ Winter } \\
\hline Months & $\begin{array}{c}\text { Total } \\
\text { monthly } \\
\text { rainfall }(\mathrm{mm})\end{array}$ & $\begin{array}{l}\text { Avg. monthly } \\
\text { min temp. } \\
\left({ }^{\circ} \mathrm{C}\right)\end{array}$ & $\begin{array}{l}\text { Avg. monthly } \\
\text { max temp. } \\
\left({ }^{\circ} \mathrm{C}\right)\end{array}$ & Months & $\begin{array}{c}\text { Total } \\
\text { monthly } \\
\text { rainfall }(\mathrm{mm})\end{array}$ & $\begin{array}{l}\text { Avg. monthly } \\
\text { min temp. } \\
\left({ }^{\circ} \mathrm{C}\right)\end{array}$ & $\begin{array}{l}\text { Avg. monthly } \\
\max \text { temp. } \\
\left({ }^{\circ} \mathrm{C}\right)\end{array}$ \\
\hline June 2014 & 179.60 & 16.60 & 26.80 & $\begin{array}{c}\text { December } \\
2014\end{array}$ & 2.60 & 4.10 & 11.70 \\
\hline July 2014 & 144.20 & 18.20 & 27.50 & January 2015 & 19.80 & 2.30 & 17.70 \\
\hline August 2014 & 432.00 & 17.60 & 26.40 & $\begin{array}{c}\text { February } \\
2015\end{array}$ & 1.20 & 4.20 & 17.90 \\
\hline
\end{tabular}

useful materials such as carotene, vitamin $\mathrm{E}$, and vitamin $\mathrm{C}$ which suggested that this alga could be used as rich source of antioxidants for health foods. Rindi et al. [29] reported the presence of abundant $\beta$-carotene and hematochrome which are responsible for imparting colour to the group Trentepohliales. Voytsekhovich and Kashevarov [30] analysed the pigments chlorophylls a-, $b$-, $\beta$-carotene and xanthophylls in Trentepohlia umbrina and reported low chlorophyll content compared to carotenoid content. Mukherjee et al. [31] reported the seasonal variation of carotenoids in two species of Trentepohlia, T. aurea growing on walls and T. cucullata growing on tree bark, where carotenoids content increased severalfold in winter compared to that in summer. Li et al. [32] demonstrated the presence of high level of carotenoids and the biosynthesis pathway in T. iolithus.

Meghalaya, a state in North Eastern part of India, is a biodiversity hotspot. Eleven species of Trentepohlia have been reported from different tree barks in this region [33]. Hence the present study emphasised on studying the seasonal variation of carotenoids in some dominant species of Trentepohlia growing luxuriantly on different substrata with the aim of assessing the potential of some Trentepohlia species as source of some important natural carotenoids such as $\beta$-carotene, $\beta$ cryptoxanthin, and lutein.

\section{Materials and Methods}

2.1. Sampling Area. Shillong the capital of Meghalaya State which lies at an average altitude of $1496 \mathrm{~m}$ a.s.l. and between latitude $25^{\circ} 30^{\prime} \mathrm{N}$ and longitude $91^{\circ} 00^{\prime} \mathrm{E}$ was selected for sampling of algal species. Shillong experiences a subtropical highland climate, where summer is cool and rainy with an average total rainfall of more than $2100 \mathrm{~mm}$ annually, while winter is usually cold and dry. The four main seasons of Shillong are spring, monsoon or summer, autumn, and winter. Spring usually runs from March to April or May while monsoons arrive in June and rains almost until the end of August or sometimes continues right to the end of September. October and November are the transition months between rainy and winter seasons. The period between December and February is winter and is characterized by cold and dry weather. Collection of samples was done at several locations within Shillong area during summer (June, July, and August) and winter (December, January, and February) of 20142015. Details of total monthly rainfall and average monthly minimum and maximum temperature of Shillong area for each sampling month are given in Table 1.

2.2. Plant Material. Four dominant species of Trentepohlia were collected at different locations from four different substrata, that is, Trentepohlia diffracta (Krempelhüber) Hariot from cemented wall, Trentepohlia arborum (C. Agardh) Hariot from rock, Trentepohlia umbrina (Kützing) Bornet from iron electric pole, and Trentepohlia abietina (Flotow) Hansgirg from three different trees with different bark characteristics, that is, Eucalyptus sp. (smooth), Pinus kesiya (fissured), and Grevillea sp. (rough). Details of species and substrata, along with sampling dates and location, are given in Table 2. The collected algal samples were freeze-dried at $-4^{\circ} \mathrm{C}$. Identification of Trentepohlia species was done using standard monographs and papers of Printz [18], Sarma [34], Rindi and Guiry [35], Rindi et al. [36, 37], and Rindi and López-Bautista [38].

2.3. Chemicals and Solvents. Standard carotenoids ( $\beta$-carotene, lutein, and $\beta$-cryptoxanthin) were obtained from Sigma Chemicals, Co. (St. Louis, MO, USA). All the chemicals and solvents used such as acetone, acetonitrile, methanol, ethyl ether, butylated hydroxyl toluene (BHT), sodium chloride $(\mathrm{NaCl})$, and potassium hydroxide $(\mathrm{KOH})$ were of HPLC/ analytical grade.

2.4. Extraction. The entire process of extraction, saponification, and spectrophotometer estimation of carotenoids was done following the procedure of Britton [39] with slight modifications. $1 \mathrm{gm}$ of freeze-dried algal filaments was homogenized with a mortar and pestle in a dark room and extracted repeatedly with acetone in the presence of butylated hydroxyl toluene (BHT) as antioxidant. The homogenate was then centrifuged and the supernatant was collected. The solid residue was recovered for further extraction. The extraction procedure was repeated until extracting solvent was colourless. The combined extract was filtered through Whatman paper number 42 to remove the residue. The acetone extract was then mixed with equal volume of ethyl ether in a separating funnel and 3\% sodium chloride solution was added until two layers separated. The upper combined ether extracts containing the carotenoids were washed three times with distilled water to remove the extracting solvent (acetone). For saponification, the above extract was dried completely 
TABLE 2: Details of four species of Trentepohlia (T. arborum, T. diffracta, T. umbrina, and T. abietina), collected from different substrata at different locations in Shillong, Meghalaya, during summer and winter months.

\begin{tabular}{|c|c|c|c|c|c|}
\hline \multirow{2}{*}{ Species } & \multirow{2}{*}{$\begin{array}{l}\text { Substrata or } \\
\text { habitat }\end{array}$} & \multirow{2}{*}{$\begin{array}{l}\text { Place of } \\
\text { sampling }\end{array}$} & \multirow{2}{*}{ Location } & \multicolumn{2}{|c|}{ Sampling dates } \\
\hline & & & & Summer & Winter \\
\hline Trentepohlia diffracta & Cement wall & $\begin{array}{l}\text { Laitumkhrah, } \\
\text { Shillong }\end{array}$ & $\begin{array}{l}\text { Altitude: } \\
1481.64 \text { m a.s.l. } \\
\text { Latitude: } 25^{\circ} 34.229^{\prime} \mathrm{N} \text {, } \\
91^{\circ} 53.432^{\prime} \mathrm{E}\end{array}$ & & \\
\hline Trentepohlia arborum & Rock & $\begin{array}{l}\text { Mawtawar, } \\
\text { Shillong }\end{array}$ & $\begin{array}{l}\text { Altitude: } \\
1406.65 \mathrm{~m} \text { a.s.l. } \\
\text { Latitude: } 25^{\circ} 37.067^{\prime} \mathrm{N}, \\
91^{\circ} 54.820^{\prime} \mathrm{E}\end{array}$ & & \\
\hline Trentepohlia umbrina & Iron electric pole & $\begin{array}{l}\text { NEHU } \\
\text { Campus, } \\
\text { Shillong }\end{array}$ & $\begin{array}{l}\text { Altitude: } 1411 \mathrm{~m} \text { a.s.l. } \\
\text { Latitude: } 25^{\circ} 36.761^{\prime} \mathrm{N} \text {, } \\
91^{\circ} 54.082^{\prime} \mathrm{E}\end{array}$ & $\begin{array}{l}\text { 18th June, } 2014 \\
\text { 21st July, } 2014 \\
\text { 23rd August, } 2014\end{array}$ & $\begin{array}{l}\text { 19th December, } 2014 \\
\text { 17th January, } 2015 \\
\text { 20th February, } 2015\end{array}$ \\
\hline Trentepohlia abietina & $\begin{array}{l}\text { Tree barks; } \\
\text { Eucalyptus sp. } \\
\text { (smooth bark), } \\
\text { Pinus kesiya } \\
\text { (fissured bark), } \\
\text { and Grevillea sp. } \\
\text { (rough bark) }\end{array}$ & $\begin{array}{l}\text { Golf Course } \\
\text { Plantation, } \\
\text { Shillong }\end{array}$ & $\begin{array}{l}\text { Altitude: } \\
\text { 1440-1448 m a.s.l. } \\
\text { Latitude: } 25^{\circ} 35.180^{\prime} \mathrm{N} \text {, } \\
91^{\circ} 53.789^{\prime} \mathrm{E}\end{array}$ & & \\
\hline
\end{tabular}

and $40 \%$ of methanolic $\mathrm{KOH}$ was added; the mixture was then allowed to stand in the dark at room temperature for about 12 hours (overnight). Equal amount of ethyl ether was added followed by sodium chloride solution till the upper ethereal phase was separated. Then the upper part was washed with distilled water. This saponified extract was dried and finally dissolved in mobile phase and filtered through $0.45 \mu \mathrm{m}$ membrane filter paper before injection.

2.5. Separation and Quantification of Carotenoids. The carotenoids were separated and identified following the procedure of Machmudah and Goto [40]. Carotenoids extracts were analysed using an HPLC Perkin Elmer series 200 equipped with Perkin Elmer Brownlee C18 column $(5 \mu \mathrm{m}$ particle sizes, $150 \times 4.6 \mathrm{~mm})$. The mobile phase consisted of isocratic solvent of methanol and acetonitrile in the ratio $90: 10$ and flow rate was maintained at $1.0 \mathrm{~mL} / \mathrm{min}$. Carotenoids were monitored at $450 \mathrm{~nm}$ using UV-visible detector. The identification of various carotenoids in Trentepohlia was carried out by comparing the retention time and absorption spectra of unknown peaks with reference standards and estimation of the quantity of each carotenoid was carried out from the chromatogram peak areas.

2.6. Statistical Analysis. All experiments were carried out with three replicates each. Two-way analysis of variance (ANOVA, $P<0.05$ ) was used to find out the significant difference in amount of total carotenoids and individual carotenoid between season (i.e., summer and winter) and amongst the different species of Trentepohlia (i.e., T. abietina, T. arborum, T. diffracta, and T. umbrina).

\section{Results}

Quantitative estimation of total carotenoids in all four species of Trentepohlia, that is, T. abietina, T. arborum, T. diffracta, and T. umbrina, by spectrophotometer showed a significant seasonal variation. Winter samples contained significantly higher total carotenoids content compared to that in summer samples. Among the four species, total carotenoids content was highest in Trentepohlia diffracta collected from cemented wall both in summer $\left(38.96 \mathrm{mg} \mathrm{g}^{-1}\right)$ and in winter (41.19 $\mathrm{mg} \mathrm{g}^{-1}$ ). Total carotenoids content was low in T. umbrina collected from electric pole where it was only $36.06 \mathrm{mgg}^{-1}$ in summer and $38.92 \mathrm{mgg}^{-1}$ in winter (Figure 1). Two-way analysis of variance (ANOVA) showed a significant difference in total carotenoids content between winter and summer $(P=0.011)$, but there was no significant difference amongst the different species of Trentepohlia $(P=0.678)$.

High Performance Liquid Chromatography (HPLC) chromatograms of different carotenoids in four species of Trentepohlia are given in Figure 2. The carotenoids separated by HPLC and identified by comparing with reference carotenoid standards were lutein (retention time $4 \mathrm{~min}$ ), $\beta$ cryptoxanthin (retention time $7 \mathrm{~min}$ ), and $\beta$-carotene (retention time $10.3 \mathrm{~min}$ ). Quantitative estimation of carotenoids from the peak area in all four species showed a similar trend where the quantitative amount of $\beta$-cryptoxanthin, lutein, and $\beta$-carotene was more in winter than in summer (Table 3 ). Among the three carotenoids studied, $\beta$-carotene was severalfold higher compared to lutein and $\beta$-cryptoxanthin. Remarkably the increase in level of $\beta$-carotene in winter samples was almost threefold compared to that of summer. In 
TABLE 3: $\beta$-Cryptoxanthin, Lutein, and $\beta$-carotene content in four species of Trentepohlia, that is, T. arborum, T. diffracta, T. umbrina, and T. abietina in summer and winter.

\begin{tabular}{|c|c|c|c|c|c|c|}
\hline & \multicolumn{2}{|c|}{$\beta$-Cryptoxanthin } & \multicolumn{2}{|c|}{ Lutein } & \multicolumn{2}{|c|}{$\beta$-Carotene } \\
\hline & $\begin{array}{l}\text { Summer } \\
\left(\mu \mathrm{gg}^{-1}\right)\end{array}$ & $\begin{array}{l}\text { Winter } \\
\left(\mu \mathrm{gg}^{-1}\right)\end{array}$ & $\begin{array}{l}\text { Summer } \\
\left(\mu \mathrm{gg}^{-1}\right)\end{array}$ & $\begin{array}{l}\text { Winter } \\
\left(\mu \mathrm{gg}^{-1}\right)\end{array}$ & $\begin{array}{l}\text { Summer } \\
\left(\mu \mathrm{gg}^{-1}\right)\end{array}$ & $\begin{array}{l}\text { Winter } \\
\left(\mu \mathrm{gg}^{-1}\right)\end{array}$ \\
\hline T. arborum & $0.0056 \pm 0.0008$ & $0.6247 \pm 0.937$ & $0.0024 \pm 0.0001$ & $0.0061 \pm 0.0001$ & $291.25 \pm 11.34$ & $605.71 \pm 3.43$ \\
\hline T. diffracta & $0.4651 \pm 0.2768$ & $2.3134 \pm 0.365$ & $0.0014 \pm 0.00008$ & $0.0051 \pm 0.00006$ & $330.87 \pm 15.61$ & $974.34 \pm 15.54$ \\
\hline T. umbrina & $0.0069 \pm 0.0018$ & $0.0692 \pm 0.044$ & $0.0009 \pm 0.00005$ & $0.0027 \pm 0.00037$ & $148.81 \pm 10.29$ & $520.17 \pm 11.85$ \\
\hline T. abietina & $0.1523 \pm 0.0259$ & $1.3399 \pm 0.289$ & $0.0026 \pm 0.0001$ & $0.0059 \pm 0.0006$ & $230.04 \pm 10.88$ & $585.27 \pm 6.66$ \\
\hline
\end{tabular}

TABLE 4: ANOVA table to show the variation in different carotenoids amongst four species of Trentepohlia (i.e., T. arborum, T. diffracta, T. umbrina, and T. abietina) and between summer and winter.

\begin{tabular}{lcccccc}
\hline & \multicolumn{2}{c}{ Cryptoxanthin } & \multicolumn{2}{c}{ Lutein } & \multicolumn{2}{c}{$\beta$-Carotene } \\
& $P$ value & $F$-value & $P$ value & $F$-value & $P$ value & \multicolumn{2}{c}{$F$-value } \\
\hline Between species & 2.363 & 0.249 & 0.078 & 6.545 & 3.295 \\
Between seasons & 0.093 & 5.893 & $\mathbf{0 . 0 0 6}^{*}$ & $\mathbf{4 5 . 5 8 3}^{*}$ & $\mathbf{0 . 0 1 1}^{*}$ & $\mathbf{3 1 . 4 6 8}^{*}$ \\
\hline
\end{tabular}

* Significant difference at $P<0.05$.

TABle 5: $\beta$-Cryptoxanthin, Lutein, and $\beta$-carotene content in T. abietina collected from trees with different bark types, Eucalyptus sp. (smooth), Pinus kesiya (fissured), and Grevillea sp. (rough) in summer and winter.

\begin{tabular}{|c|c|c|c|c|c|c|}
\hline & \multicolumn{2}{|c|}{$\beta$-Cryptoxanthin } & \multicolumn{2}{|c|}{ Lutein } & \multicolumn{2}{|c|}{$\beta$-Carotene } \\
\hline & $\begin{array}{l}\text { Summer } \\
\left(\mu \mathrm{gg}^{-1}\right)\end{array}$ & $\begin{array}{l}\text { Winter } \\
\left(\mu \mathrm{gg}^{-1}\right)\end{array}$ & $\begin{array}{l}\text { Summer } \\
\left(\mu \mathrm{gg}^{-1}\right)\end{array}$ & $\begin{array}{l}\text { Winter } \\
\left(\mu \mathrm{gg}^{-1}\right)\end{array}$ & $\begin{array}{l}\text { Summer } \\
\left(\mu \mathrm{gg}^{-1}\right)\end{array}$ & $\begin{array}{l}\text { Winter } \\
\left(\mu \mathrm{gg}^{-1}\right)\end{array}$ \\
\hline T. abietina (from Eucalyptus sp.) & $0.1013 \pm 0.0041$ & $2.1268 \pm 0.5526$ & $0.0045 \pm 0.0003$ & $0.0082 \pm 0.00032$ & $278.04 \pm 12.04$ & $622.82 \pm 1.10$ \\
\hline T. abietina (from Grevillea sp.) & $0.3521 \pm 0.0732$ & $1.2449 \pm 0.0683$ & $0.0011 \pm 0.0001$ & $0.0026 \pm 0.0013$ & $262.66 \pm 12.71$ & $615.30 \pm 1.07$ \\
\hline T. abietina (from Pinus sp.) & $0.0034 \pm 0.0005$ & $0.6481 \pm 0.2480$ & $0.0021 \pm 0.0001$ & $0.0068 \pm 0.00037$ & $149.41 \pm 7.89$ & $517.68 \pm 17.81$ \\
\hline
\end{tabular}

TABLE 6: ANOVA table to show the variation in different carotenoids content of Trentepohlia abietina in two seasons, that is, summer and winter, and between the different barks characters (smooth, fissured, and rough).

\begin{tabular}{lcccccc}
\hline \multirow{2}{*}{ Trentepohlia abietina } & \multicolumn{2}{c}{ Cryptoxanthin } & \multicolumn{2}{c}{ Lutein } & \multicolumn{2}{c}{$\beta$-Carotene } \\
& $P$ value & $F$-value & $P$ value & $F$-value & $P$ value & $F$-value \\
\hline Between different barks characters & 0.463 & 1.162 & 0.118 & 7.487 & $\mathbf{0 . 0 0 8}^{*}$ & $\mathbf{1 1 6 . 2 6 3}^{*}$ \\
Between seasons & 0.108 & 7.811 & 0.076 & 11.68 & $\mathbf{0 . 0 0 0 3}^{*}$ & $\mathbf{2 6 5 0 . 1 3 8}^{*}$ \\
\hline
\end{tabular}

${ }^{*}$ Significant difference at $P<0.05$.

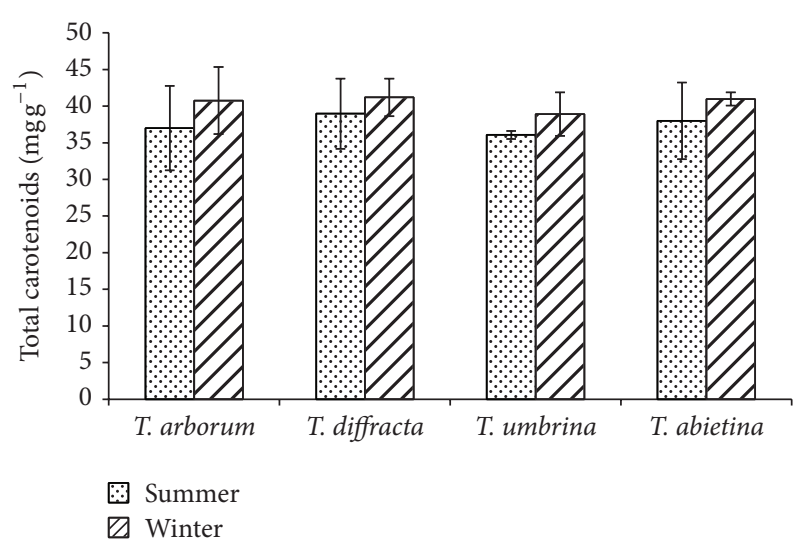

FIGURE 1: Total carotenoid content $\left(\mathrm{mg} \mathrm{g}^{-1}\right)$ of Trentepohlia arborum, T. diffracta, T. umbrina, and T. abietina in summer and winter. Error bars represent standard deviation. winter, the highest amount of $\beta$-carotene was observed in $T$. diffracta collected from wall $\left(974.34 \pm 15.54 \mu \mathrm{g} \mathrm{g}^{-1}\right)$, followed by $T$. arborum collected from rock $\left(605.71 \pm 3.43 \mu \mathrm{g} \mathrm{g}^{-1}\right)$ and T. abietina collected from bark $\left(585.27 \pm 6.66 \mu \mathrm{g} \mathrm{g}^{-1}\right)$, and least amount was in T. umbrina collected from electric pole $\left(520.17 \pm 11.85 \mu \mathrm{g} \mathrm{g}^{-1}\right)$. Lutein and $\beta$-carotene content showed significant seasonal variations, but when compared between four species of Trentepohlia collected from four substrata, no significant differences could be observed (Table 4).

Assessment of carotenoids content in Trentepohlia abietina collected from different types of barks revealed that sample collected from smooth bark had maximum amount of carotenoids (lutein, $\beta$-cryptoxanthin, and $\beta$-carotene) both in summer and in winter, followed by sample from rough bark and minimum amount was noted in fissured bark of Pinus kesiya (Table 5). $\beta$-Carotene in winter sample collected 

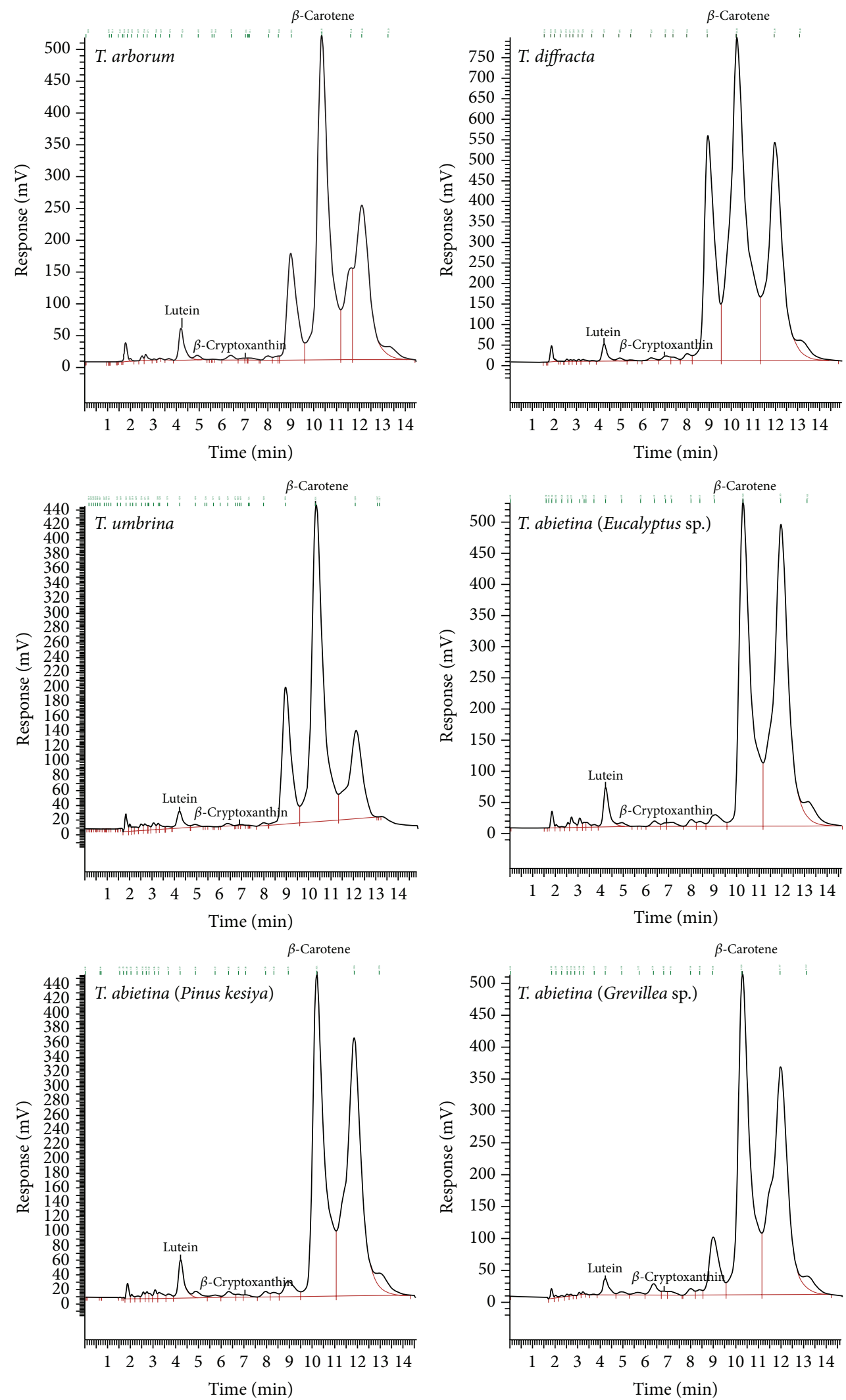

FIGURE 2: HPLC chromatogram for T. arborum (rock), T. diffracta (wall), T. umbrina (electric pole), and T. abietina (collected from bark of Eucalyptus sp., Pinus kesiya, and Grevillea sp.). Column C18, $5 \mu \mathrm{m}$ particle sizes, $150 \times 4.6 \mathrm{~mm}, 90: 10 \mathrm{methanol} /$ acetonitrile mobile phase, $1.0 \mathrm{~mL} / \mathrm{min}$ flow rate, and detection wavelength at $450 \mathrm{~nm}$. 
from smooth bark of Eucalyptus sp. was as high as $622.82 \pm$ $1.10 \mu \mathrm{g} \mathrm{g}^{-1}$. Significant difference in quantity of $\beta$-carotene was recorded in Trentepohlia abietina collected from different barks types $(P=0.008)$ while in case of Lutein and $\beta$ cryptoxanthin there was no significant difference (Table 6).

\section{Discussion}

A significant seasonal variation was clearly observed in this study where carotenoids were higher in winter compared to summer. High content of carotenoids in winter season with threefold increase in quantity of $\beta$-carotene in all four species of Trentepohlia could be due to light, water, and temperature stresses. Shillong, lying at an average altitude of $1496 \mathrm{~m}$ a.s.l., experiences high light irradiance during daytime accompanied by dryness and low average temperature $\left(2.3^{\circ} \mathrm{C}-\right.$ $18^{\circ} \mathrm{C}$ ), which could be the reason for the enhancement of carotenoids production during winter. Increased production of carotenoids at high light intensity had been reported by Tan et al. [41] in Trentepohlia odorata and by Abe et al. [27] in Trentepohlia aurea. Low temperature along with high light intensity had been reported to induce carotenogenesis and enhanced $\beta$-carotene production [42-44]. Ben-Amotz [45] reported that there was a fourfold increase in the 9-cis/alltrans $\beta$-carotene ratio in Dunaliella bardawil when culture temperature was lowered from $30^{\circ} \mathrm{C}$ to $10^{\circ} \mathrm{C}$. Furthermore, it was reported that disruption of cell membrane integrity takes place at low temperature and thereby making the algae more susceptible to photooxidation [46, 47]. Hence, high amount of carotenoids is accumulated in some microalga as a protective measure to overcome photoinhibition and oxidative stress [48-52]. Similarly, these four species of Trentepohlia (T. abietina, T. arborum, T. diffracta, and T. umbrina) accumulated large quantity of carotenoids, especially $\beta$ carotene during winter, where temperature is low and photon irradiance is high accompanied by severe dryness as a strategy to protect the cells from photodamage or injury. On the other hand low amount of carotenoids content in summer samples of Trentepohlia could be attributed to high rainfall which is a common phenomenon in this region. This region is known as one of the wettest regions of the world. Taken as total of all the three summer months together (June, July, and August) $755.8 \mathrm{~mm}$ of rainfall was recorded during the experimental period. Constant supply of water or moisture in the form of heavy rainfall accompanied by cloudy days might have added to low carotenoids production in summer. According to Mukherjee et al. [31] low carotenoid content in T. aurea and T. cucullata in Assam during summer could be due to high temperature and cloudy days which was unfavourable for the growth of Trentepohlia. The highest accumulation of carotenoids in T. diffracta collected from wall and T. arborum collected from rock could be due to high light and water stress which consequently resulted in production of more carotenoids in the filaments for protection against oxidation, since the bare rocks and walls were more exposed to sunlight and dryness. Bartley and Scolni [53] documented that carotenoids played an important role as light-harvesting pigments and protect the photosynthetic apparatus from photooxidative damage under excess light conditions. Again the significant difference in amount of $\beta$-carotene in Trentepohlia abietina collected from different bark characters showed that smooth bark played an important role in controlling the growth and carotenoids production in Trentepohlia. Low moisture holding capacity and full exposure to light could be the reasons for maximum accumulation of carotenoids to overcome those stresses in smooth bark.

\section{Conclusion}

This study had provided valuable information on some important carotenoids biosynthesized by Trentepohlia, whereby assessment of three important carotenoids content from four different species of Trentepohlia, that is, Trentepohlia abietina, T. arborum, T. diffracta, and T. umbrina, collected from different substrata had shown higher amount of $\beta$-carotene accumulation which highlighted the potential of utilising Trentepohlia for the production of $\beta$-carotene.

\section{Conflict of Interests}

The authors hereby declare that there is no conflict of interests regarding the publication of this paper. They also declare that this paper has not been published elsewhere and is not currently under consideration by another journal published by Hindawi or any other publisher, and the submission of the paper is approved by the institution.

\section{Acknowledgments}

The authors would like to acknowledge University Grant Commission for the financial assistance. They are thankful to Centre for Advance Studies in Botany and the Head Department of Botany for providing all the laboratory facilities. They are also grateful to Directorate of Agriculture, Shillong, Meghalaya, for providing them with environmental parameters data.

\section{References}

[1] G. Britton, S. Liaaen-Jensen, and H. Pfander, Carotenoids Handbook, Birkhäuser, Basel, Switzerland, 2004.

[2] B. Halliwell and J. M. C. Gutteridge, Free Radicals in Biology and Medicine, Oxford University Press, New York, NY, USA, 1999.

[3] A. Bendich and J. A. Olson, "Biological actions of carotenoids," The FASEB Journal, vol. 3, no. 8, pp. 1927-1932, 1989.

[4] D. Yuan, L. Bassie, M. Sabalza et al., "The potential impact of plant biotechnology on the Millennium Development Goals," Plant Cell Reports, vol. 30, no. 3, pp. 249-265, 2011.

[5] G. Britton, S. Liaaen-Jensen, and H. Pfander, Carotenoids: Natural Functions, vol. 4 of Carotenoids, Birkhäuser, 2008.

[6] D. E. Breithaupt and A. Bamedi, "Carotenoid esters in vegetables and fruits: a screening with emphasis on $\beta$-cryptoxanthin esters," Journal of Agricultural and Food Chemistry, vol. 49, no. 4, pp. 2064-2070, 2001.

[7] T. Grune, G. Lietz, A. Palou et al., " $\beta$-carotene is an important vitamin A source for humans," The Journal of Nutrition, vol. 140, no. 12, pp. 2268S-2285S, 2010. 
[8] G. W. Burton and K. U. Ingold, “ $\beta$-Carotene: an unusual type of lipid antioxidant," Science, vol. 224, no. 4649, pp. 569-573, 1984.

[9] H. Sies and W. Stahl, "Vitamins E and C, $\beta$-carotene, and other carotenoids as antioxidants," The American Journal of Clinical Nutrition, vol. 62, no. 6, pp. 1315S-1321S, 1995.

[10] L. Mueller and V. Boehm, "Antioxidant activity of $\beta$-carotene compounds in different in vitro assays," Molecules, vol. 16, no. 2, pp. 1055-1069, 2011.

[11] M. L. Slattery, J. Benson, K. Curtin, K.-N. Ma, D. Schaeffer, and J. D. Potter, "Carotenoids and colon cancer," American Journal of Clinical Nutrition, vol. 71, no. 2, pp. 575-582, 2000.

[12] T. Narisawa, Y. Fukaura, S. Oshima, T. Inakuma, M. Yano, and H. Nishino, "Chemoprevention by the oxygenated carotenoid $\beta$-cryptoxanthin of $\mathrm{N}$-methylnitrosourea-induced colon carcinogenesis in F334 rats," Japanese Journal of Cancer Research, vol. 90, no. 10, pp. 1061-1065, 1999.

[13] M. P. A. Zeegers, R. A. Goldbohm, and P. A. van den Brandt, "Are retinol, vitamin $\mathrm{C}$, vitamin $\mathrm{E}$, folate and carotenoids intake associated with bladder cancer risk? Results from the Netherlands Cohort study," British Journal of Cancer, vol. 85, no. 7, pp. 977-983, 2001.

[14] K. R. Martin, M. L. Failla, and J. C. Smith Jr., " $\beta$-Carotene and lutein protect HepG2 human liver cells against oxidantinduced damage," Journal of Nutrition, vol. 126, no. 9, pp. 20982106, 1996.

[15] A. Sujak, J. Gabrielska, W. Grudziński, R. Borc, P. Mazurek, and W. I. Gruszecki, "Lutein and zeaxanthin as protectors of lipid membranes against oxidative damage: the structural aspects," Archives of Biochemistry and Biophysics, vol. 371, no. 2, pp. 301307, 1999.

[16] J. M. Seddon, U. A. Ajani, R. D. Sperduto et al., "Dietary carotenoids, vitamins $\mathrm{A}, \mathrm{C}$, and $\mathrm{E}$, and advanced age-related macular degeneration," The Journal of the American Medical Association, vol. 272, no. 18, pp. 1413-1420, 1994.

[17] R. A. Bone, J. T. Landrum, Z. Dixon, Y. Chen, and C. M. Llerena, "Lutein and zeaxanthin in the eyes, serum and diet of human subjects," Experimental Eye Research, vol. 71, no. 3, pp. 239-245, 2000.

[18] H. Printz, "Vorarbeiten zu einer monographie der trentepohliaceen," Nytt Magasin for Naturvidenskapene, vol. 80, pp. 137210, 1939.

[19] R. L. Chapman, "An assessment of the current state of our knowledge of the Trentepohliaceae," in Systematics of the Green Algae, pp. 233-250, Academic Press, London, UK, 1984.

[20] J. M. López-Bautista, D. A. Waters, and R. L. Chapman, "The Trentepohliales Revisited," Constancea 83, 2002, http://ucjeps .berkeley.edu/constancea/83/lopez_etal/trentepohliales.html.

[21] R. L. Chapman and D. A. Waters, "Lichenization of the trentepohliales: complex algae and odd relationships," in Symbiosis: Mechanisms and Model Systems, J. Seckbach, Ed., vol. 4 of Cellular Origin, Life in Extreme Habitats and Astrobiology, pp. 359-371, Springer, Dordrecht, The Netherlands, 2002.

[22] J. M. López-Bautista, F. Rindi, and M. D. Guiry, "Molecular systematics of the subaerial green algal order Trentepohliales: an assessment based on morphological and molecular data," International Journal of Systematic and Evolutionary Microbiology, vol. 56, no. 7, pp. 1709-1715, 2006.

[23] P. Gaylarde, G. Englert, O. Ortega-Morales, and C. Gaylarde, "Lichen-like colonies of pure Trentepohlia on limestone monuments," International Biodeterioration and Biodegradation, vol. 58, no. 3-4, pp. 119-123, 2006.
[24] H. Kjosen, N. Arpin, and S. Liaaen-Jensen, "The carotenoids of Trentepohlia iolithus. Isolation of $\beta, \beta$-carotene-2-ol, $\beta, \varepsilon$ carotene-2-ol and $\beta, \beta$-carotene-2, $2^{\prime}$-diol," Acta Chemical Scandinavica, vol. 26, pp. 3053-3067, 1972.

[25] G. Nybraaten and S. Liaaen-Jensen, "Algal carotenoids. XI. New carotenoid epoxides from Trentepohlia iolithus," Acta Chemical Scandinavica, vol. 28, p. 483, 1974.

[26] B. Czezuga and O. Maximov, "Carotenoids in the cell of alga Trentepohlia gobii Meyer," Acta Societatis Botanicorum Poloniae, vol. 65, pp. 273-276, 1996.

[27] K. Abe, H. Mihara, and M. Hirano, "Characteristics of growth and carotenoid accumulation of the aerial microalga Trentepohlia aurea in liquid culture," Journal of Marine Biotechnology, vol. 6, no. 1, pp. 53-58, 1998.

[28] K. Abe, N. Nishimura, and M. Hirano, "Simultaneous production of $\beta$-carotene, vitamin $\mathrm{E}$ and vitamin $\mathrm{C}$ by the aerial microalga Trentepohlia aurea," Journal of Applied Phycology, vol. 11, no. 4, pp. 331-336, 1999.

[29] F. Rindi, D. W. Lam, and J. M. López-Bautista, "Phylogenetic relationships and species circumscription in Trentepohlia and Printzina (Trentepohliales, Chlorophyta)," Molecular Phylogenetics and Evolution, vol. 52, no. 2, pp. 329-339, 2009.

[30] A. A. Voytsekhovich and G. P. Kashevarov, "Pigment content of photosynthetic apparatus of green algae (Chlorophyta) - the photobionts of lichens," International Journal on Algae, vol. 12, no. 3, pp. 282-292, 2010.

[31] R. Mukherjee, S. P. Borah, and B. C. Goswami, "Biochemical characterization of carotenoids in two species of Trentepohlia (Trentepohliales, Chlorophyta)," Journal of Applied Phycology, vol. 22, no. 5, pp. 569-571, 2010.

[32] Q. Li, J. Liu, L. Zhang, and Q. Liu, "De novo transcriptome analysis of an aerial microalga Trentepohlia jolithus: pathway description and gene discovery for carbon fixation and carotenoid biosynthesis," PLoS ONE, vol. 9, no. 9, Article ID e108488, pp. 1-14, 2014.

[33] D. Kharkongor and P. Ramanujam, "Diversity and species composition of subaerial algal communities in forested areas of Meghalaya, India," International Journal of Biodiversity, vol. 2014, Article ID 456202, 10 pages, 2014.

[34] P. Sarma, "The fresh water chaetophorales of New Zealand," Beihefte Nova Hedwigia, vol. 58, pp. 1-69, 1986.

[35] F. Rindi and M. D. Guiry, "Diversity, life history, and ecology of Trentepohlia and Printzina (Trentepohliales, Chlorophyta) in urban habitats in Western Ireland," Journal of Phycology, vol. 38, no. 1, pp. 39-54, 2002.

[36] F. Rindi, A. R. Sherwood, and M. D. Guiry, "Taxonomy and distribution of Trentepohlia and Printzina (Trentepohliales, Chlorophyta) in the Hawaiian Islands," Phycologia, vol. 44, no. 3, pp. 270-284, 2005.

[37] F. Rindi, M. D. Guiry, and J. M. López-Bautista, "New records of Trentepohliales (Ulvophyceae, Chlorophyta) from Africa," Nova Hedwigia, vol. 83, no. 3-4, pp. 431-449, 2006.

[38] F. Rindi and J. M. López-Bautista, "New and interesting records of Trentepohlia (Trentepohliales, Chlorophyta) from French Guiana, including the description of two new species," Phycologia, vol. 46, no. 6, pp. 698-708, 2007.

[39] G. Britton, "General carotenoid methods," Methods in Enzymology, vol. 111, pp. 113-149, 1985.

[40] S. Machmudah and M. Goto, "Methods for extraction and analysis of carotenoids," in Natural Products, K. G. Ramawat and J. M. Mérillon, Eds., pp. 3367-3411, Springer, Berlin, Germany, 2013. 
[41] C. K. Tan, Y. K. Lee, and K. K. Ho, "Effect of light intensity and ammonium-N on carotenogenesis of Trentepohlia odorata and Dunaliella bardawil," Journal of Applied Phycology, vol. 5, no. 5, pp. 547-549, 1993.

[42] V. E. Semenenko and A. A. Abdullaev, "Parametric control of $\beta$ carotene biosynthesis in Dunaliella bardawil cells from intense culture conditions," Soviet Plant Physiology, vol. 27, pp. 31-41, 1980.

[43] H. Mendoza, M. J. del Rio, G. G. Reina, and Z. Ramazanov, "Low-temperature-induced oil-carotene and fatty acid synthesis, and ultrastructural reorganization of the chloroplast in Dunaliella salina (Chlorophyta)," European Journal of Phycology, vol. 31, pp. 329-331, 1996.

[44] R. R. Bidigare, M. E. Ondrusek, M. C. Kennicutt et al., "Evidence a photoprotective for secondary carotenoids of snow Algae," Journal of Phycology, vol. 29, no. 4, pp. 427-434, 1993.

[45] A. Ben-Amotz, "Effect of low temperature on the stereoisomer composition of $\beta$-carotene in the halotolerant alga Dunaliella bardawil (Chlorophyta)," Journal of Phycology, vol. 32, no. 2, pp. 272-275, 1996.

[46] J. A. Raven and R. J. Geider, "Temperature and algal growth," New Phytologist, vol. 110, no. 4, pp. 441-461, 1988.

[47] I. Nishida and N. Murata, "Chilling sensitivity in plants and cyanobacteria: the crucial contribution of membrane lipids," Annual Review of Plant Physiology and Plant Molecular Biology, vol. 47, no. 1, pp. 541-568, 1996.

[48] A. Ben-Amotz, A. Katz, and M. Avron, "Accumulation of $\beta$ carotene in halotolerant algae: purification and characterization of $\beta$-carotene-rich globules from Dunaliella bardawil (Chlorophyceae)," Journal of Phycology, vol. 18, no. 4, pp. 529-537, 1982.

[49] A. Ben-Amotz and M. Avron, "On the factors which determine massive $\beta$-carotene accumulation in the halotolerant alga Dunaliella bardawil," Plant Physiology, vol. 72, no. 3, pp. 593597, 1983.

[50] A. Ben-Amotz and M. Avron, "The wavelength dependence of massive carotene synthesis in Dunaliella bardawil (chlorophyceae)," Journal of Phycology, vol. 25, no. 1, pp. 175-178, 1989.

[51] L. S. Jahnke, "Massive carotenoid accumulation in Dunaliella bardawil induced by ultraviolet-A radiation," Journal of Photochemistry and Photobiology B: Biology, vol. 48, no. 1, pp. 68-74, 1999.

[52] D. S. Pisal and S. S. Lele, "Carotenoid production from microalga, Dunaliella salina," Indian Journal of Biotechnology, vol. 4, no. 4, pp. 476-486, 2005.

[53] G. E. Bartley and P. A. Scolnik, "Plant carotenoids: pigments for photoprotection, visual attraction, and human health," Plant Cell, vol. 7, no. 7, pp. 1027-1038, 1995. 

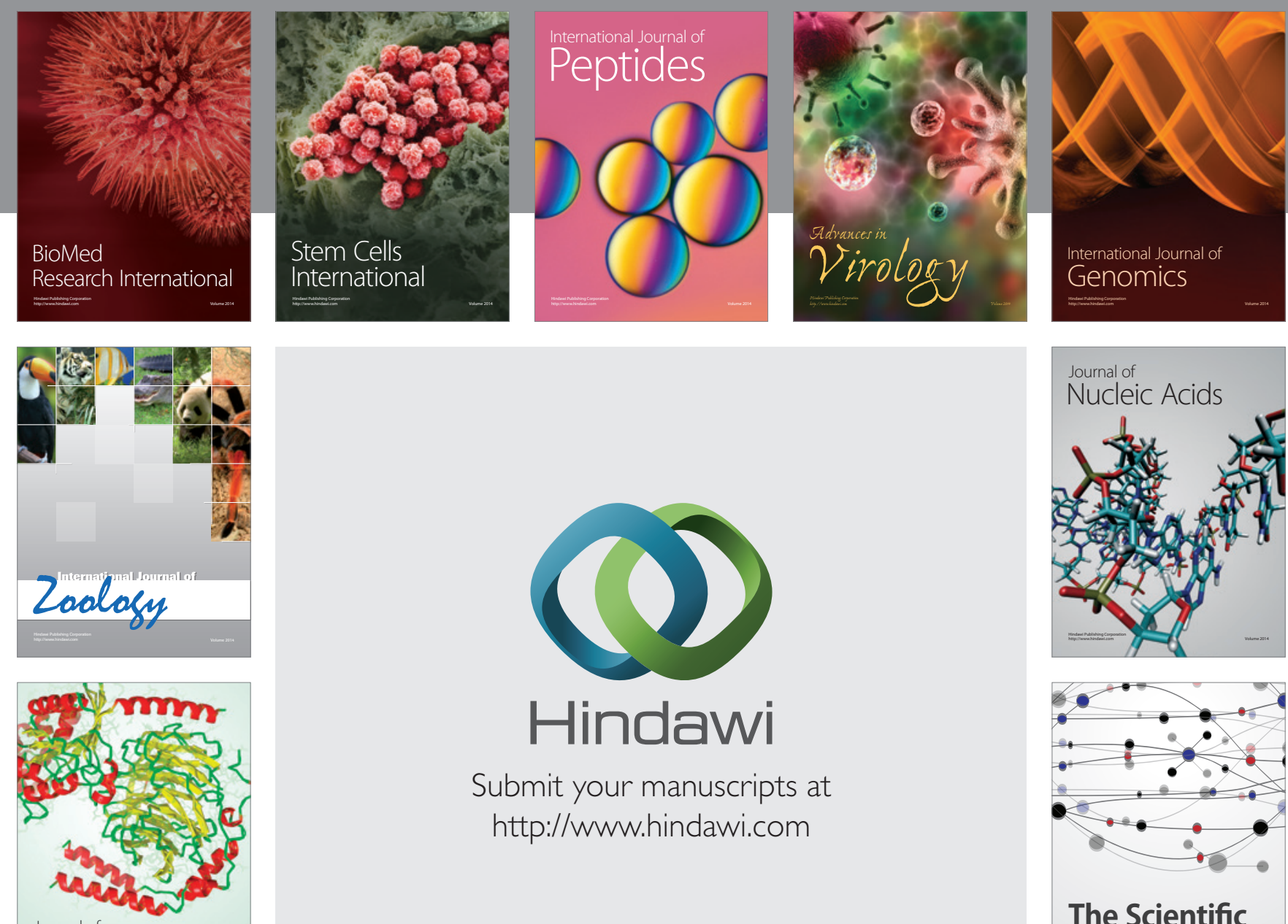

Submit your manuscripts at

http://www.hindawi.com

Journal of
Signal Transduction
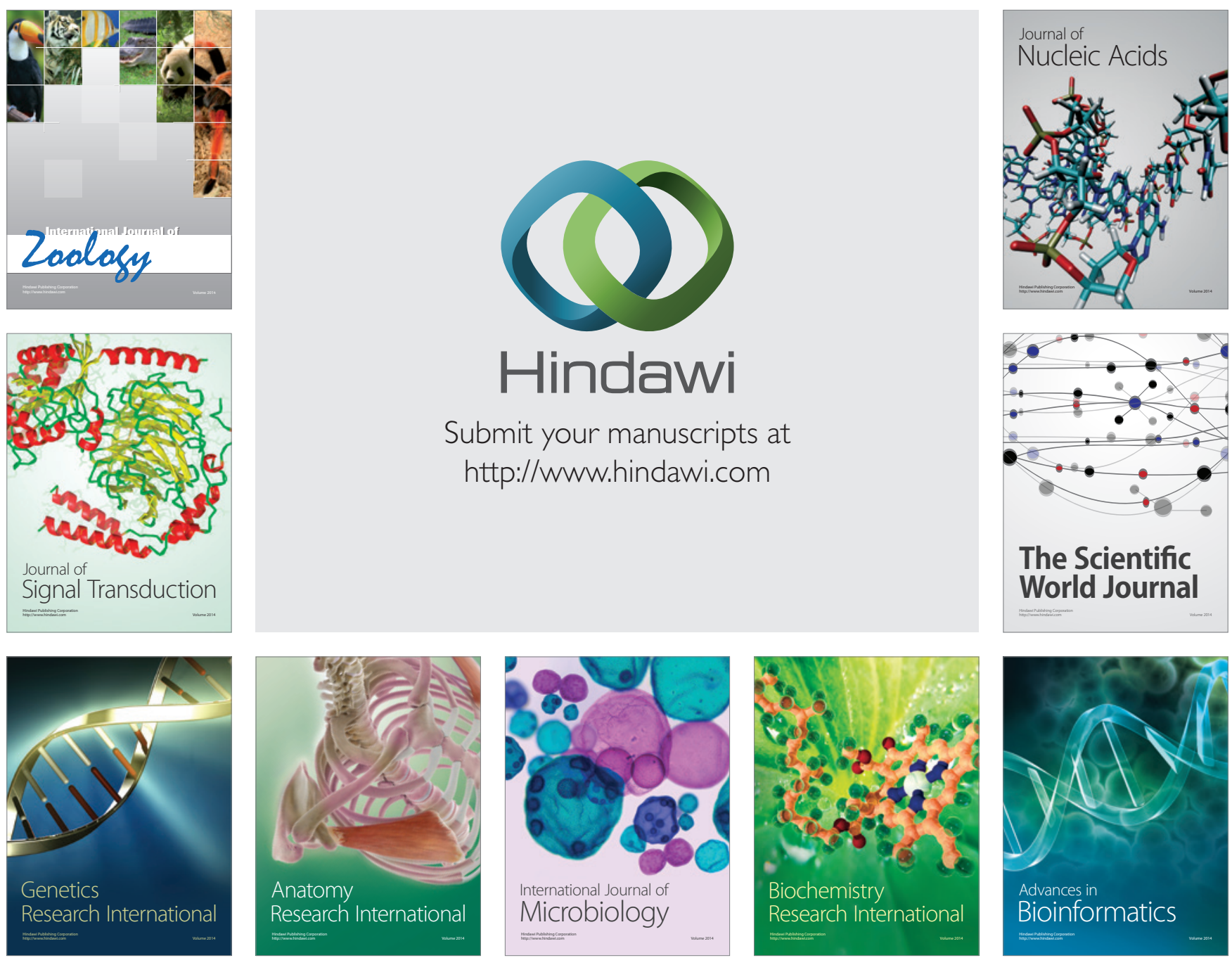

The Scientific World Journal
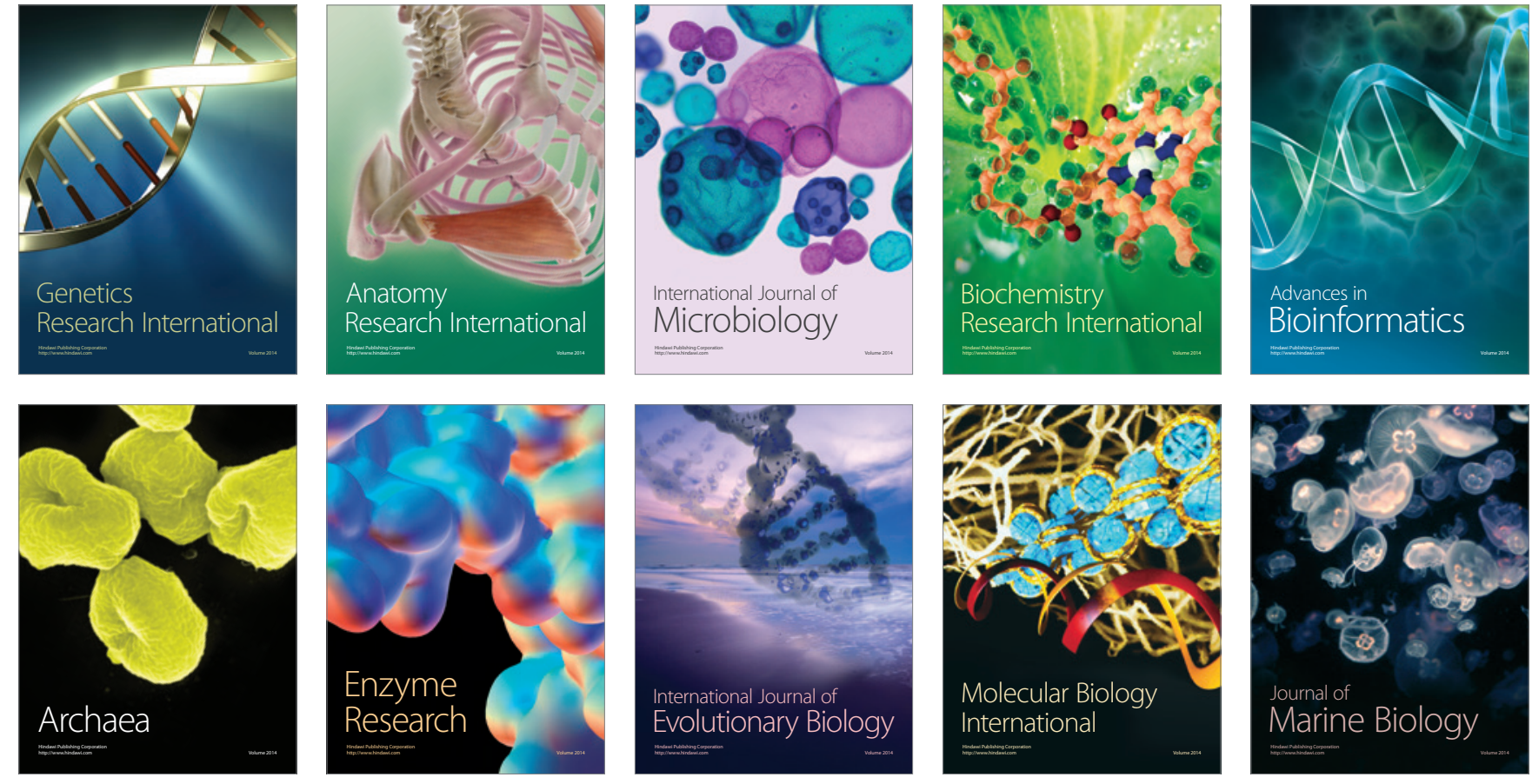